\title{
Transmission of Pigeon Pea Sterility Mosaic Virus and Management of Sterility Mosaic Disease of Pigeonpea by Different Acaricides under Middle IGP of Bihar
}

\author{
Rahul Kumar Maurya ${ }^{1^{*}}$, Birendra Kumar ${ }^{1}$, Rahul Kumar $^{2^{*}}$ and Mukesh Singh ${ }^{3}$ \\ ${ }^{1}$ Department of Plant Pathology, Dr. Rajendra Prasad Central Agricultural University, \\ Pusa, Bihar, India \\ ${ }^{2}$ Division of Crop Research, ICAR-Research Complex for Eastern Region Patna, Bihar, India \\ ${ }^{3}$ Department of Horticulture, Institute of Agricultural Sciences, Banaras Hindu University, \\ Varanasi, U.P., India \\ *Corresponding author
}

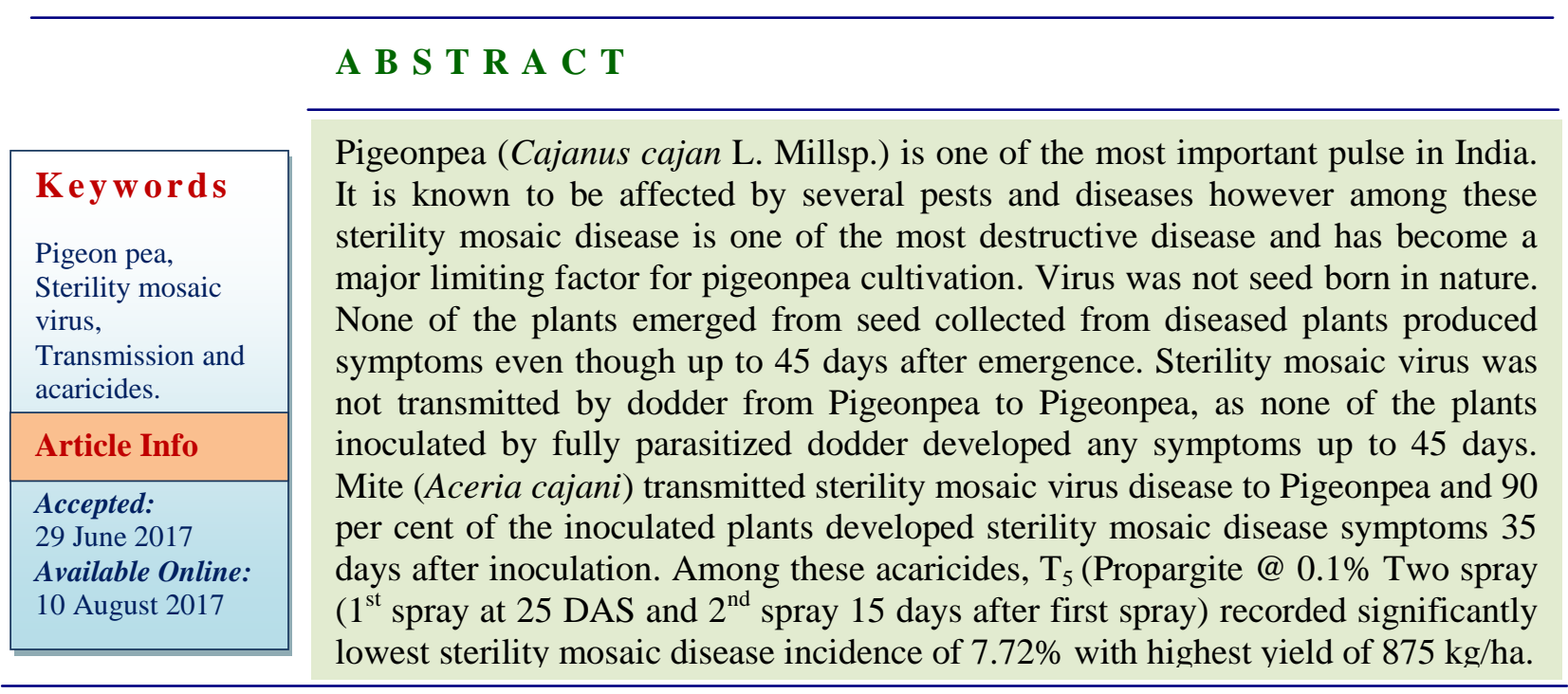

\section{Introduction}

Pigeonpea is one of the most important pulse crop grown in Asia. In India, Pigeonpea was grown on 3.88 million ha, with annual production of 3.17 million tonnes and average productivity of $812 \mathrm{~kg} / \mathrm{ha}$ during the year 2013-14. Pigeonpea, sterility mosaic disease (PSMD) is the most damaging disease of pigeon pea (Cajanus cajan) in the Indian subcontinent. PPSMV is transmitted by the eriophyidmite, Aceria cajani Channabasavanna (Acari: Arthropoda) (Ghanekaret al., 1992; Seth, 1962).
Analysis of mite populations obtained from SMD affected plants from several locations in India, Nepal, and Myanmar has indicated that A. cajani transmits PPSMV at all of these locations (Kumar et al., 2001). It is transmitted by Eriophyid mite (Aceria cajani) and is now considered as one of the most serious disease of Pigeonpea. An early infection can reduce grain yield up to 100 per cent. The disease has been reported in all states wherever the Pigeonpea is grown. In the absence of resistance varieties, the 
available control measures are not adequate to manage the disease. In present investigation methods of transmission and use of acaricides, four methods used for the transmission of sterility mosaic disease namely seed, sap, dodder and mite (Aceria cajani) transmission. The virus was readily transmissible by mites but not by sap, seed or through dodder.

\section{Materials and Methods}

\section{Mechanical transmission}

\section{Maintenance of Pigeonpea sterility mosaic disease nursery}

A field was selected to ensure that it is isolated from other Pigeonpea field to avoid spread of the viral inoculum from this plot to other for survival of Eriophyid mites. The plot was maintained adequate shadow, a highly susceptible genotype (ICP 8863) was sown two month earlier than the normal planting schedule of Pigeonpea, the plants were inoculated using leaf stapling technique at the 2-3 leaf stage, irrigation was given frequently to insure the optimum temperature required for survival of mite transmission of the disease. The plant showed 100 per cent sterility mosaic infection 60 days after sowing. The virus and mites multiply on these nursery plants and serve as source of inoculum for the transmission studies.

\section{Preparation of inoculum}

The virus inoculum was prepared from freshly collected young diseased leaves of Pigeonpea. These were washed with tap water followed by distilled water. The adhering water was removed by placing the leaves in between two folds of blotting paper. The diseased leaves were ground in $0.1 \mathrm{M}$ phosphate buffer having $\mathrm{pH} 7.0$ by pestle and mortar. In the leaf tissues phosphate buffer was added in ratio of 1:1 (W/V). The sap are extracted through two layer of muslin cloth and collected in a beaker. The sap thus obtained was centrifuged at 5,000 rpm for 20 min. The supernatant was used as inoculum. Hence forth this inoculum is called as "standard inoculum". Before inoculation a pinch of celite powder (200 mesh) which acts as abrasive was either added in the inoculum mixed thoroughly or dusted over the leaf surface which was to be inoculated.

\section{Preparation of phosphate buffer}

\section{Stock solution}

$0.2 \mathrm{M}$ solution of monobasic potassium phosphate $\left(\mathrm{KH}_{2} \mathrm{PO}_{4} .2 .720 \mathrm{~g}\right.$ in $100 \mathrm{ml}$ Distilled water).

$0.2 \mathrm{M}$ solution of dibasic sodium phosphate $\left(\mathrm{Na}_{2} \mathrm{HPO}_{4} \cdot 7 \mathrm{H}_{2} \mathrm{O} .5 .360 \mathrm{~g}\right.$ in $100 \mathrm{ml}$ distilled water).

$39 \mathrm{ml}$ of (a) and $61 \mathrm{ml}$ of (b) were mixed and diluted to $200 \mathrm{ml}$ with distilled water to prepare $0.1 \mathrm{M}$ solution at $\mathrm{pH} 7.0$.

\section{Mechanical transmission through sap inoculation}

Attempts were made to transmit the virus by mechanical inoculation through sap inoculation to Pigeonpea. In all the experiments wherever sap inoculation was to be done, plants were inoculated with freshly prepared standard inoculum. Absorbent cotton was soaked in the inoculum and three leaves of apparently healthy looking plant were inoculated. A high susceptible variety ICP 8863 was used for inoculation. The plants were inoculated at first trifoliate stage. Too old and too young leaves were discarded. A small quantity of celite powder was dusted on leaves before inoculation. Prior to inoculation the plants were kept in darkness for 12 hour to 
make them susceptible to infection. At the time of inoculation leaves were supported from below with the help of a piece of card board and then the cotton soaked in the inoculum was gently rubbed on the upper surface. The plants were immediately washed with tap water to remove excess of inoculum and inhibitors over there. Inoculated plants were then kept in the glasshouse and observed daily for production of symptoms.

\section{Transmission through seed}

100 seeds collected from diseased plants and 100 seeds from healthy plants of Pigeonpea Variety ICP 8863, highly susceptible were sown in pot maintaining five plants in each pot. After recording germination percentage, the seedlings were kept in insect proof condition for symptom production.

\section{Transmission through dodder (Cascutare flexa Roxb.)}

The growing ends of the dodder (Cascutare flexa Roxb.) Collected from healthy weeds (Lantana camara, Eichornia crassipes etc.) were twined to young growing shoots of sterility mosaic disease infected Pigeonpea plants and the growing end of dodder, established on diseased plant was twined on the young shoots of healthy test plants. The dodder so established was allowed to grow as bridge between donor and recipient plants for 30 days and then removed. The test plants were kept in insect proof net house for symptom production.

\section{Transmission through Eriophyid mites (Aceria cajani)}

Leaf collected from diseased plants carrying a number of Eriophyid mite Aceria cajani (confirmed under stereoscopic binocular microscope) were stapled to the healthy test plants of Pigeonpea. The inoculated (stapled) plants of Pigeonpea were kept in insect proof net house for symptoms development. An experiment was conducted during Kharif season 2014-15 at research area Tirhut College of Agriculture, Dholi, Muzaffarpur (Dr. Rajendra Prasad Central Agricultural University, Pusa, Bihar), to evaluate the efficiency of various management practices in controlling sterility mosaic disease with the following treatments.

\section{Treatments}

$\mathrm{T}_{1}$ - Neem oil @ 3\% - two spray ( $1^{\text {st }}$ spray 25 DAS and $2^{\text {nd }}$ spray after 15 days of $1^{\text {st }}$ spray)

$\mathrm{T}_{2}$ - NSKE (Neem Seed Kernel Extract)@ $5 \%$ - two spray $\left(1^{\text {st }}\right.$ spray 25 DAS and $2^{\text {nd }}$ spray after 15 days of $1^{\text {st }}$ spray)

$\mathrm{T}_{3}$ - Fenazaquin @ 0.1\% - two spray ( $1^{\mathrm{st}}$ spray 25 DAS and $2^{\text {nd }}$ spray after 15 days of $1^{\text {st }}$ spray)

$\mathrm{T}_{4}$ - Dicofol @0.2\% - two spray ( $1^{\text {st }}$ spray 25 DAS and $2^{\text {nd }}$ spray after 15 days of $1^{\text {st }}$ spray)

$\mathrm{T}_{5}$ - Propargite @ $0.1 \%$ - two spray ( ${ }^{\text {st }}$ spray 25 DAS and $2^{\text {nd }}$ spray after 15 days of $1^{\text {st }}$ spray)

$\mathrm{T}_{6}$ - Wettablesulphur @ $0.25 \%$ - two spray $\left(1^{\text {st }}\right.$ spray 25 DAS and $2^{\text {nd }}$ spray after 15 days of $1^{\text {st }}$ spray)

$\mathrm{T}_{7}$ - Control (No spray)

\section{Results and Discussion}

\section{Mode of transmission}

\section{Mechanical transmission through sap}

Sap inoculation of virus causing sterility mosaic virus disease was carried out on Pigeonpea variety ICP 8863. The results showed that the virus was not sap transmissible. None of the plant produced 
symptoms even upto 45 days after inoculation (Tables 1 and 5).

\section{Seed transmission}

A study on seed transmission on sterility mosaic virus disease was carried out as described in materials and methods. The result revealed that virus was not seed born in nature. None of the plants emerged from seed collected from diseased plants produced symptoms even though up to 45 days after emergence (Tables 2 and 5).

\section{Dodder transmission}

Studies on dodder transmission of the virus were carried out as described in "Materials and Methods". The results indicated that sterility mosaic virus was not transmitted by dodder from Pigeonpea to Pigeonpea, as none of the plants inoculated by fully parasitized dodder developed any symptoms up to 45 days (Tables 3 and 5).

\section{Mite transmission}

Mites (Aceria cajani) were used for transmission of sterility mosaic virus as described under "Materials and Methods". Mite (Aceria cajani) transmitted sterility mosaic virus disease to Pigeonpea and 90 per cent of the inoculated plants developed sterility mosaic disease symptoms 35 days after inoculation (Table 4 and 5). One study suggested that PPSMV was not transmitted transovarially by $A$. cajani but was transmitted in a persistent manner provided mites continue to feed on susceptible plants (Reddy et al., 1989).

Table.1 Transmission through sap inoculation

\begin{tabular}{|l|c|c|c|c|}
\hline $\begin{array}{c}\text { Date of } \\
\text { inoculation }\end{array}$ & $\begin{array}{c}\text { No. of plant } \\
\text { inoculated }\end{array}$ & $\begin{array}{c}\text { No. of infected } \\
\text { plant }\end{array}$ & $\begin{array}{c}\text { Date of disease } \\
\text { appearance }\end{array}$ & $\begin{array}{c}\text { Incubation period } \\
\text { (Days) }\end{array}$ \\
\hline 06.08 .2014 & 10 & 0 & 0 & 0 \\
\hline 11.08 .2014 & 10 & 0 & 0 & 0 \\
\hline 16.08 .2014 & 10 & 0 & 0 & 0 \\
\hline 20.08 .2014 & 10 & 0 & 0 & 0 \\
\hline 25.08 .2014 & 10 & 0 & 0 & 0 \\
\hline
\end{tabular}

Table.2 Transmission through seed

\begin{tabular}{|l|c|c|c|c|}
\hline $\begin{array}{c}\text { Pigeonpea seed } \\
\text { collected from }\end{array}$ & $\begin{array}{c}\text { No. of seeds } \\
\text { sown }\end{array}$ & $\begin{array}{c}\text { No. of seeds } \\
\text { germinated }\end{array}$ & $\begin{array}{c}\text { No. of plant showing } \\
\text { symptoms/healthy }\end{array}$ & $\begin{array}{c}\text { Percent seed } \\
\text { transmission }\end{array}$ \\
\hline Disease plants & 100 & 90 & $0 / 90$ & 0.00 \\
\hline Healthy plants & 100 & 95 & $0 / 95$ & 0.00 \\
\hline
\end{tabular}

Table.3 Transmission through Dodder

\begin{tabular}{|c|c|c|}
\hline Date of Inoculation & $\begin{array}{c}\text { No. of plant inoculated } \\
\text { with Parasitized Dodder }\end{array}$ & No. of infected plant \\
\hline 01.09 .2014 & 5 & $0 / 5$ \\
\hline 06.09 .2014 & 5 & $0 / 5$ \\
\hline 10.09 .2014 & 5 & $0 / 5$ \\
\hline 15.09 .2014 & 5 & $0 / 5$ \\
\hline
\end{tabular}


Table.4 Transmission through mite

\begin{tabular}{|c|c|c|c|}
\hline \multirow{2}{*}{ Mite } & \multicolumn{2}{|c|}{ Total no. of plant } & \multirow{2}{*}{$\begin{array}{c}\text { Infection } \\
\text { (\%) }\end{array}$} \\
\cline { 2 - 3 } & Inoculated & Infected & 90 \\
\hline Eriophyid mite (Aceria cajani) & 200 & 180 & 90 \\
\hline
\end{tabular}

Table.5 Transmission studies on sterility mosaic disease

\begin{tabular}{|c|l|c|c|c|}
\hline $\begin{array}{c}\text { Sl. } \\
\text { No. }\end{array}$ & \multicolumn{1}{|c|}{ Method of inoculation } & $\begin{array}{l}\text { Total No. of plants infected } \\
\text { Total No. of plants inoculated }\end{array}$ & $\begin{array}{c}\text { Disease } \\
(\boldsymbol{\%})\end{array}$ & $\begin{array}{c}\text { Period taken for } \\
\text { symptoms } \\
\text { expression (Days) }\end{array}$ \\
\hline 1. & Mechanical & $0 / 50$ & - & - \\
\hline 2. & Seed & $0 / 200$ & - & - \\
\hline 3. & Dodder & $0 / 20$ & - & - \\
\hline 4. & Eriophyid mite (Aceria cajani & $180 / 200$ & 90.0 & 35 \\
\hline
\end{tabular}

Table.6 Evaluation of different Acaricides for control of mite (Aceria cajani)

\begin{tabular}{|c|c|c|c|}
\hline SI. No. & Treatments & Incidence $(\%)$ & Yield (Kg/ha) \\
\hline $\mathbf{T}_{1}$ & $\begin{array}{l}\text { Neem oil @ } 3 \% \text { Two spray ( } 1^{\text {st }} \text { spray at } 25 \text { DAS and } 2^{\text {nd }} \\
\text { spray } 15 \text { days after first spray) }\end{array}$ & $27.22(31.43)$ & 270.00 \\
\hline $\mathbf{T}_{2}$ & $\begin{array}{l}\text { N.S.K.E. @ } 5 \% \text { Two spray }\left(1^{\text {st }} \text { spray at } 25 \text { DAS and } 2^{\text {nd }}\right. \\
\text { spray } 15 \text { days after first spray) }\end{array}$ & $33.10(35.10)$ & 201.25 \\
\hline $\mathbf{T}_{3}$ & $\begin{array}{l}\text { Fenzaquin @ } 0.1 \% \text { Two spray ( } 1^{\text {st }} \text { spray at } 25 \text { DAS and } \\
2^{\text {nd }} \text { spray } 15 \text { days after first spray) }\end{array}$ & $15.27(22.98)$ & 642.50 \\
\hline $\mathbf{T}_{4}$ & $\begin{array}{l}\text { Dicofol @ } 0.2 \% \text { Two spray }\left(1^{\text {st }} \text { spray at } 25 \text { DAS and } 2^{\text {nd }}\right. \\
\text { spray } 15 \text { days after first spray) }\end{array}$ & $10.42(18.81)$ & 727.50 \\
\hline$T_{5}$ & $\begin{array}{l}\text { Propargite @ } 0.1 \% \text { Two spray ( } 1^{\text {st }} \text { spray at } 25 \text { DAS and } \\
2^{\text {nd }} \text { spray } 15 \text { days after first spray) }\end{array}$ & $7.72(16.10)$ & 875.00 \\
\hline$T_{6}$ & $\begin{array}{l}\text { W. S. @ } 0.25 \% \text { Two spray ( } 1^{\text {st }} \text { spray at } 25 \text { DAS and } 2^{\text {nd }} \\
\text { spray } 15 \text { days after first spray) }\end{array}$ & $40.91(39.74)$ & 142.50 \\
\hline $\mathbf{T}_{7}$ & Control & $71.85(57.94)$ & 95.00 \\
\hline & LSD at $5 \%$ & 2.54 & 82.00 \\
\hline & $\mathrm{SE}(\mathrm{m})$ & 0.85 & 27.38 \\
\hline & C.V. & 5.77 & 12.98 \\
\hline
\end{tabular}

Among these, $\mathrm{T}_{5}$ (Propargite @ 0.1\% Two spray $\left(1^{\text {st }}\right.$ spray at 25 DAS and $2^{\text {nd }}$ spray 15 days after first spray) recorded significantly lowest sterility mosaic disease incidence of $7.72 \%$ with highest yield of $875 \mathrm{~kg} / \mathrm{ha}$ followed by $\mathrm{T}_{4}$ (Dicofol @ 0.2\% Two spray $\left(1^{\text {st }}\right.$ spray at 25 DAS and $2^{\text {nd }}$ spray 15 days after first spray) 10.42 per cent (yield of 727.5 $\mathrm{kg} / \mathrm{ha}$ ) and $\mathrm{T}_{3}$ (Fenzaquin @ 0.1\% Two spray $\left(1^{\text {st }}\right.$ spray at 25 DAS and $2^{\text {nd }}$ spray 15 days after first spray) incidence $15.27 \%$ (642.5 $\mathrm{kg} / \mathrm{ha}$ ) (Table 6). While untreated control showed highest sterility mosaic disease incidence of $71.85 \%$ with lowest yield of 95 $\mathrm{kg} / \mathrm{ha}$. All the treatments have shown significant among themselves. Some studies have been conducted earlier (Rathi 1983, Reddy et al.,1990), seed dressing with 25\% Carbofuran or 10\% Aldicarb @ 3g/kg seed in helpful in protecting the crop at early stage up to 45 days after sowing. 
In conclusion, Virus was not seed born in nature. None of the plants emerged from seed collected from diseased plants produced symptoms even though up to 45 days after emergence. Sterility mosaic virus was not transmitted by dodder from Pigeonpea to Pigeonpea, as none of the plants inoculated by fully parasitized dodder developed any symptoms up to 45 days. Mite (Aceria cajani) transmitted sterility mosaic virus disease to pigeonpea and 90 per cent of the inoculated plants developed sterility mosaic disease symptoms 35 days after inoculation. Among these acaricides, $\mathrm{T}_{5}$ (Propargite @ 0.1\% Two spray ( $1^{\text {st }}$ spray at $25 \mathrm{DAS}$ and $2^{\text {nd }}$ spray 15 days after first spray) recorded significantly lowest sterility mosaic disease incidence of $7.72 \%$ with highest yield of $875 \mathrm{~kg} / \mathrm{ha}$.

\section{References}

Ghanekar, A. M., Sheila, V. K., Beniwal, S. P. S., Reddy, M. V., Nene, Y. L. (1992). Sterility mosaic of pigeonpea. pp 415428.

Kumar, P. L., Fenton, B., Duncan, G., Jones, A. T., Sreenivasulu, P., Reddy, D.V.R. (2001). Assessment of variation in Aceria cajani (Acari: Eriophyidae) using analysis of nuclear rDNA ITS region and scanning electron microscopy: implication for the variability observed in host plant resistance to Pigeonpea sterility mosaic disease. Ann. Biol. 139: 61-73.

Rathi, Y. P. S. (1983). Studies on sterility mosaic disease of Pigeonpea, Cajanus cajan (L.) Millsp.).Final technical report. Govind Ballabh Pant University of Agriculture and Technology, Pantnagar, India.P. 31.

Reddy, M. V., Arjunan, N. and Muniyappa, V. (1990).Sarvival of Pigeonpea sterility mosaic pathogen and its vector during summer in Southern India.Inter. Pigeonpea Newsl.11: 16-17.

Reddy, M. V., Beniwal, S. P. S., Sheila, V. K., Sithanathan, S., Nene, Y.L. (1989).Role of eriophyid mite (Aceria cajani) in transmission and spread of sterility mosaic of Pigeonpea. 121-127 ppIn: Progress in Acerology. G. P. Channabasavanna and C. A. Virakthmath, eds. Oxford and IBH Publishing Co. new Delhi India.

Seth, M. L. (1962). Transmission of Pigeonpea sterility by eriophyid mite. Indian Phytopathology.15: 225 - 227.

\section{How to cite this article:}

Rahul Kumar Maurya, Birendra Kumar, Rahul Kumar and Mukesh Singh. 2017. Transmission of Pigeon Pea Sterility Mosaic Virus and Management of Sterility Mosaic Disease of Pigeonpea by Different Acaricides under Middle IGP of Bihar. Int.J.Curr.Microbiol.App.Sci. 6(8): 3711-3716. doi: https://doi.org/10.20546/ijcmas.2017.608.448 